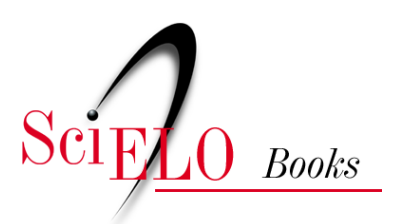

\title{
Reflexões \\ Axé para a Oi Kabum
}

\author{
Nelson De Luca Pretto
}

PRETTO, N.D.L. Axé para a Oi Kabum. In: Educações, culturas e hackers: escritos e reflexões [online]. Salvador: EDUFBA, 2017, pp. 124-125. ISBN: 978-85-232-2019-8.

https://doi.org/10.7476/9788523220198.0023.

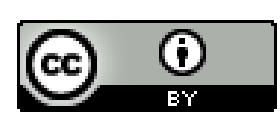

All the contents of this work, except where otherwise noted, is licensed under a Creative Commons Attribution $\underline{4.0 \text { International license. }}$

Todo o conteúdo deste trabalho, exceto quando houver ressalva, é publicado sob a licença $\underline{\text { Creative Commons }}$ Atribição 4.0.

Todo el contenido de esta obra, excepto donde se indique lo contrario, está bajo licencia de la licencia $\underline{\text { Creative }}$ Commons Reconocimento 4.0. 
organiza aos dias 5 de cada mês, um minuto de sirene, cobrando responsabilidade daqueles que espalharam lama em nossas vidas.

Temos energia para desfazer a urucubaca instalada em 2015. Pois que venha 2016. Vamos fazer os seus dias, com muito ativismo, luta política, garra e alegria. Afinal, sem alegria e festa, a gente não se move. Eppur si muove.

Publicado na Revista Muito, do jornal A Tarde, em 20 de dezembro de 2015, na matéria especial sobre o final do ano intitulada Já vai tarde.

\section{Axé para a Oi Kabum!}

Em novembro de 2015, comemoramos aqui na Bahia os 25 anos do Projeto Axé, com festa e, ao mesmo tempo, preocupação com a sua manutenção, que vem se dando a duras penas. Desde há muito, o Axé vem lutando para sobreviver, mesmo fazendo tão espetacular trabalho de formação da juventude, reconhecido em todo o mundo.

Hoje, acordamos com uma lamentável notícia do fim do apoio da operadora Oi ao projeto das escolas Oi Kabum que, espalhadas por quatro cidades brasileiras, faz um genial trabalho de empoderamento das juventudes. Ações que articulam arte, tecnologia, educação e cidadania.

Não tenho dúvida de que esses são projetos que dão vazão à criação, à inventividade, à explosão de ideias que emanam de cada um dos participantes, hoje crianças, adolescentes e jovens, os adultos do nosso futuro.

São turbilhões criativos que explodem aqui na Bahia, Minas, Pernambuco, Rio e em todos os lugares do mundo onde a liberdade de expressão e de criação impera.

Momentos de crise deveriam servir para avançar na criação de novas ideias e para o pensar grande. No entanto, lamentavelmente, a primei- 
ra solução encontrada por aqueles que apoiam projetos como as Escolas Oi Kabum é o cancelamento do apoio, o que implicará o fechamento de projetos fundantes e estruturantes que têm feito a diferença na sociedade.

Essas "escolas" estão, de fato, formando cidadãos que passam a ser programadores da produção (e da sociedade) e não meros reprodutores e consumidores de produtos ou de informações. Não podemos esquecer que estamos nos referindo à formação de jovens, portanto, uma turma que seguramente, tendo uma sólida e ampla formação, fará a diferença no futuro.

Esse ano fui convidado pela equipe da Oi Kabum para escrever o texto de um livro para celebrar os 12 anos do projeto. ${ }^{22}$ Mal sabia que estava, com aquele texto, escrevendo um epitáfio e não um texto comemorativo. Lá dizia que essas experiências têm a riqueza da possibilidade de remixar tudo: tecnologias, diálogos entre lugares, valores culturais fortalecidos, fortalecendo, assim, os processos formativos centrados numa perspectiva autoral.

As escolas precisam, então, se constituir em espaços vivos de estímulo à produção e à comunicação, implantando o que denomino de círculo virtuoso de produção de culturas e conhecimentos e não apenas de consumo de informações. Instala-se a remixagem total, para a alegria geral!

Estou neste momento no Recife e escrevo para conclamar os empresários brasileiros a olharem com mais carinho para esses projetos. Aqui nesta cidade, caldo de muita cultura, referencio um pernambucano danado, Lenine, que ao comemorar os seus 30 anos de carreira, afirmou ser um artista "raiz e antena ao mesmo tempo." Assim como ele, essas juventudes estão sedentas por uma outra escola, por outras escolas, aqui também na perspectiva plural. Querem também ser raiz e antena. Querem juntar tudo, artes, ciências, saberes, tecnologias, solidariedades, generosidades, para ajudar na construção de outras educações e de uma sociedade justa.

Não deixemos esses projetos morrerem. Axé, Oi Kabum!

Publicado no jornal A Tarde, Salvador, em 9 de dezembro de 2015.

\footnotetext{
${ }^{22}$ Esse texto, levemente modificado, é o capítulo "Arte e Tecnologia: uma chave para outras educações" no início desse livro.
} 